\title{
IMPROVING BASIC PHYSICAL ABILITIES ON UNIVERSITY STUDENTS
}

Andreea VOINEA ${ }^{1}$

\begin{abstract}
The development of physical qualities, it is a primary goal of physical education and sport for all educational cycles. The purpose of this study was to find out if basic physical abilities can be improved through physical education classes on university students. This longitudinal study was conducted in the first semester of the university year 2018-2019 in the sports halls of the Bucharest Academy of Economic Studies, on a sample of 71 female students with ages between 18 and 21 years old. We assessed mobility, strength, coordination, and endurance at the beginning and at the end of the first semester. After the statistic and graphic interpretation, we could say that the students' physical abilities were improved.
\end{abstract}

Keywords: physical education, mobility, strength, coordination, endurance

JEL classification: I. Health, Education and Welfare, I.O. General

DOI: 10.24818/mrt.20.11.02.05

\section{Introduction}

University physical education classes should be seen not only as a way to educate motor skills or a certain sporting technique but as a component of a process of instruction and education of great complexity, with extensions in future employee's activity.

It is necessary to study the possibility of orientation in physical education and sports curricula content area, providing the graduate a specific training for the profession for which he/she is preparing.

The development of physical or motor qualities, it is a primary goal of physical education and sport for all educational cycles. The method of operation is the decision of the teacher, who must find the most effective and attractive means exercises adjusted at the age of the students.

"The motor capacity/motor skill is the totality of motoric possibilities natural and acquired, which make possible to achieve a variety of efforts as structure and dosage" ${ }^{2}$. They consider that "physical abilities are a complex of motoric

\footnotetext{
${ }^{1}$ Department of Physical Education and Sport, Bucharest University of Economic Studies

${ }^{2}$ Dragnea A., Bota A, 1999, p. 41
} 
manifestations, conditioned by the development level of the motor skill, by the morpho-functional index, mental processes and by the biochemical and metabolic processes. All these summed up, correlated and mutually conditioned, will have as a result the efficient performing of the actions required by the specific conditions in which the motric skill will be performed" 3 .

"The physical qualities are native in character, the level of initial manifestation depends on the hereditary genetic background. Their subsequent development, as well as the formation of motor skills, is achieved with the evolution of growth and development process, they are influenced by specific activities, living conditions, heredity, climate and geographical environment, training” 4

There are five basic physical qualities or abilities (BPA): strength, endurance/resistance, speed, coordination and flexibility. "Research on the requirements needed in hundreds' of jobs has identified nine physical abilities involved in the performance of physical tasks.

These are -dynamic strength, static strength, trunk strength, explosive strength, extent flexibility, dynamic flexibility, body - coordination, balance and stamina". ${ }^{5}$

Stănciulescu quoted Siclovan: "Speed and strength development is done by methods which involve a predominantly ANAEROBIC effort and of endurance and mobility, through methods that involve the manifestation of a predominantly AEROBIC effort" ${ }^{6}$.

"The development level of basic physical abilities is essential for obtaining performance in physical education and sport and it contributes to the successful performance in professional activity. We may consider that the development of physical skills affects directly the activity and improvement of the main functions of the body, the increase of effort capacity, the development of the spirit of observation, imagination, inventive thinking, tenacity, perseverance and courage" ${ }^{\text {". }}$.

\section{Study Aim}

The purpose of this study was to find out if students' basic physical abilities can be improved through physical education classes. „One of the main goals of physical education is to help students learn the values and skills for a healthy life style and to enhance their overall growth and harmonious development." 8

\section{Methods}

\footnotetext{
${ }^{3}$ Dragnea A., Bota A, 1999, p.44

${ }^{4}$ Ceban I., 2016, p.73

5 iedunote.com

${ }^{6}$ Stănciulescu R., 2016, p.60

${ }^{7}$ Stănciulescu R., 2016, p.59

${ }^{8}$ Pop, C., 2015, p.
} 
The study was a longitudinal one and it was conducted in the first semester of the university year 2018-2019, from October 2018 until January 2019, in the sports halls of the Bucharest Academy of Economic Studies, on a sample of 71 female students with ages between 18 and 21 years old, mean age 19,06 $\pm 0,71$.

Figure 1. - Percentage of age

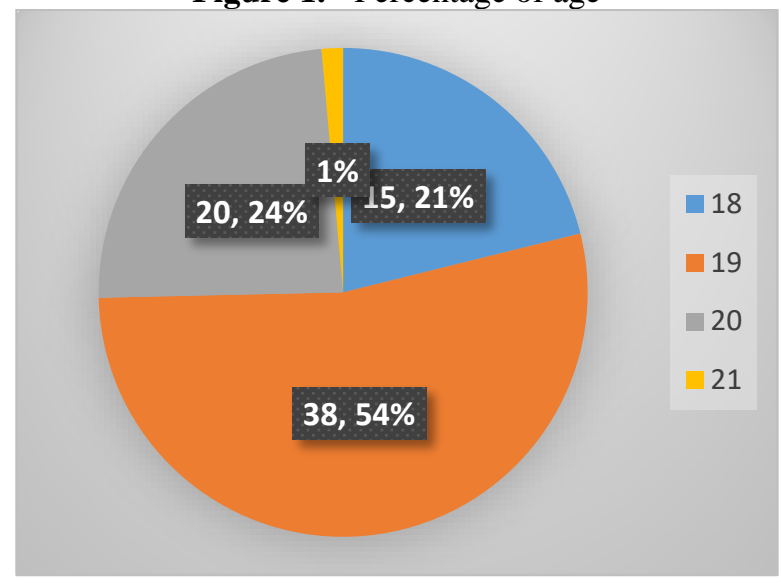

The initial assessment of mobility, strength, coordination and endurance was conducted in October 2018. After that students attended compulsory physical education and sports classes once a week. At the end of the first semester, the physical abilities were tested again.

In order to assess flexibility, we used the toe touch test ${ }^{9}$. The subject stands erect, bare-footed and feet slightly apart. The subject then bends at the waist to lean slowly forwards to attempt to touch the ground with their finger-tips, the hand flat with the finger outstretched. Bouncing and jerking are not allowed. The examiner holds a ruler on the ground, the zero mark at the ground level. The knees must be kept straight. If the subject touches the ground with the palm, repeat the test with closed legs. We noted:

1. If the fingertips are above $10 \mathrm{~cm}$;

2. If the fingertips are between 1 and $10 \mathrm{~cm}$;

3. If fingertips touch the ground with legs apart

4. If palms touch the ground with legs apart;

5. If fingertips touch the ground with closed legs;

6. If palms touch the ground with closed legs.

For strength assessment, the students were asked to perform extended leg sits up, lateral lunges and incline push-ups. The maximum number of executions required was 30 . Only the executions correctly performed were noted.

For endurance assessment, the students were asked to perform 20 jumps up burpees. Only the executions correctly performed were noted.

${ }^{9}$ Soares de Araujo, C. G., 2004, p. 42 
Jump up burpee description: the subject begins in a standing position. She moves into a squat position with hands on the ground. She kicks her feet back into a plank position while keeping her arms extended. Immediately returns her feet into a squat position. She jumps straight up as high as possible with the arms stretched up at the end of the movement, before beginning the next burpee ${ }^{10}$.

For coordination assessment, the students were asked to perform 10 jumping jacks. Jumping jack is an exercise performed by jumping to a position with the legs spread wide and the hands touching overhead, and then returning to a position with the feet together and the arms extended at the sides at shoulders level.

At the end of the initial and final assessment of students, they were asked how many times a week they practice physical exercises.

\section{FINDINGS and DISCUSSIONS}

\section{Flexibility}

Table 1. - Flexibility results

\begin{tabular}{|l|l|l|}
\hline Statistics & Initial & Final \\
\hline Min & $0-6$ students & $0-2$ students \\
\hline Max & $5-2$ students & $5-16$ students \\
\hline Mean & 2.2 & 3.38 \\
\hline STDEV & 1.29 & 2.04 \\
\hline
\end{tabular}

Figure 2. - Flexibility means

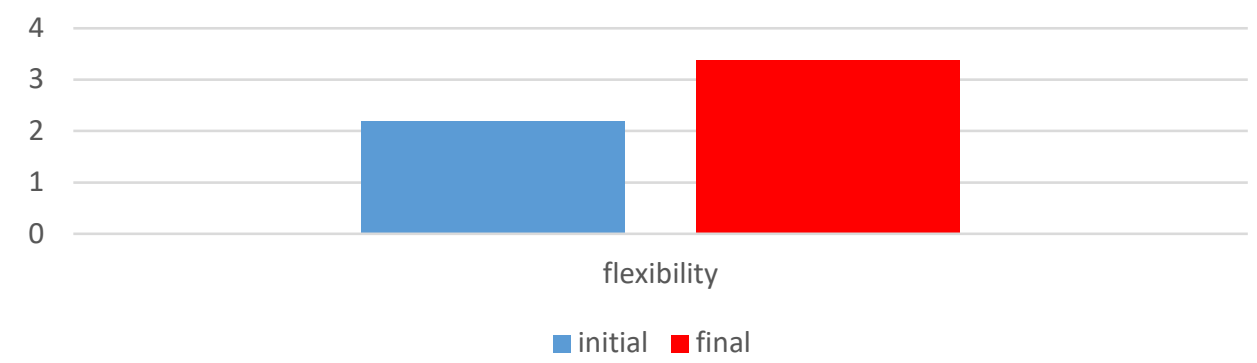

At the end of the first semester, we noticed an improvement of flexibility means 3.39 compared to 2.20 at the first assessment. At the initial assessment, we noted that 6 students had a 0 score and 2 students had a maximum score and at the final assessment only 2 students had the minimum score and 16 students performed the maximum score.

Figure 3. Percentage of flexibility results

${ }^{10}$ en.wikipedia.org 
weaker results

better results

same results

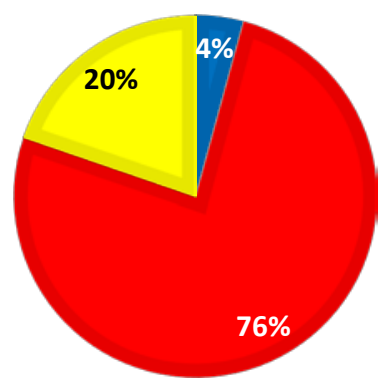

Flexibility final results revealed that 54 students had progressed, 14 students had the same results and 3 of them had weaker results.

After the statistic and graphic interpretation, we could say that students' flexibility was improved.

\section{Strength}

Table 2. Strength results

\begin{tabular}{|c|c|c|c|c|c|c|}
\hline & \multicolumn{2}{|c|}{ extended leg sits up } & \multicolumn{2}{|c|}{ lateral lunges } & \multicolumn{2}{|c|}{ incline push-ups } \\
\hline Statistics & Initial & Final & Initial & Final & Initial & Final \\
\hline Min & $\begin{array}{c}1-2 \\
\text { students }\end{array}$ & $\begin{array}{c}2-3 \\
\text { students }\end{array}$ & $\begin{array}{c}0-8 \\
\text { students }\end{array}$ & $\begin{array}{c}0-4 \\
\text { students }\end{array}$ & $\begin{array}{c}0-2 \\
\text { students }\end{array}$ & $\begin{array}{c}0-1 \\
\text { student }\end{array}$ \\
\hline Max & $\begin{array}{c}30-10 \\
\text { students }\end{array}$ & $\begin{array}{l}30-14 \\
\text { students }\end{array}$ & $\begin{array}{c}30-2 \\
\text { students }\end{array}$ & $\begin{array}{c}30-12 \\
\text { students }\end{array}$ & $\begin{array}{c}24-2 \\
\text { students }\end{array}$ & $\begin{array}{l}30-13 \\
\text { students }\end{array}$ \\
\hline Mean & 17.03 & 19.42 & 10.07 & 14.69 & 12.87 & 18.75 \\
\hline STDEV & 8.19 & 8.18 & 8.27 & 10.27 & 7.07 & 8.52 \\
\hline
\end{tabular}

Figure 4. Strength means

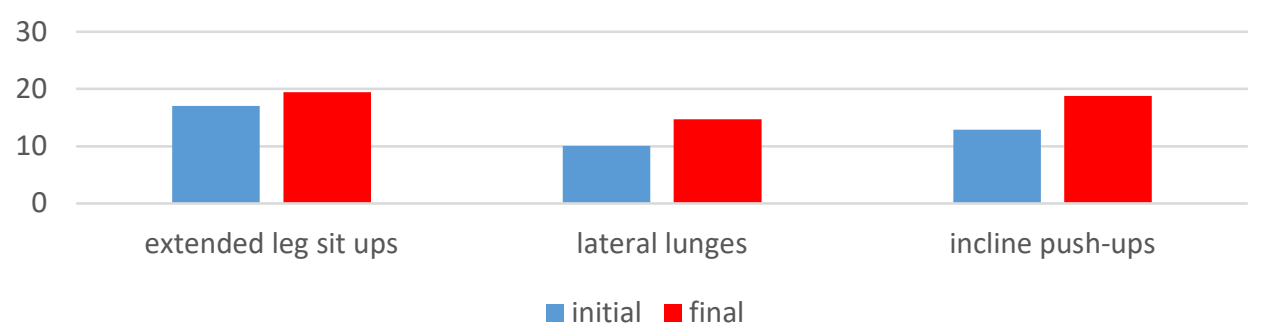

At the end of the first semester, we noticed an improvement of strength means - 19.42 compared to 17.03 (extended legs sit-ups), 14.69 compared to 10.07 (lateral lunges) and 18.75 compared to 12.87 (incline push-ups) at the first assessment.

In the strength assessment we recorded that: 
- Initially, 2 students performed 1 extended leg sit-up and finally, 3 students performed only 3 sit-ups

- Initially, 10 students performed 30 extended leg sit-ups and finally, 14 students performed the maximum number required of sit-ups.

- Initially, 8 students couldn't do any lateral lunges and finally, 4 of them couldn't do any lateral lunges;

- Initially, only 2 students did the maximum number of lateral lunges and finally, 12 students did 30 lateral lunges.

- Initially, 2 students couldn't do any incline push-ups and finally, 1 student couldn't do any push-ups.

- Initially, only 2 students could do 24 incline push-ups and finally, 13 students could perform the maximum number of push-ups.

Figure 5. Percentage of extended leg sit ups results

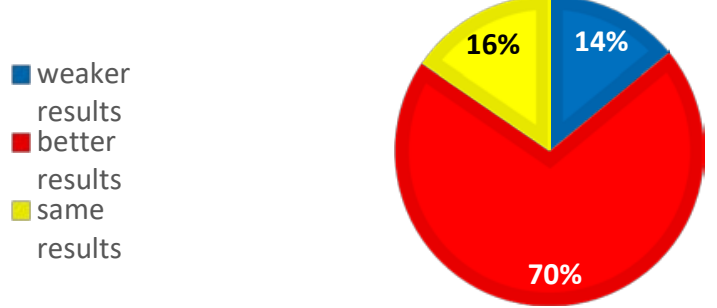

The final results for the extended leg sit-ups revealed that 50 students had progressed, 11 students had the same results and 10 of them had weaker results after a semester of physical education.

Figure 6. Percentage of lateral lunges results

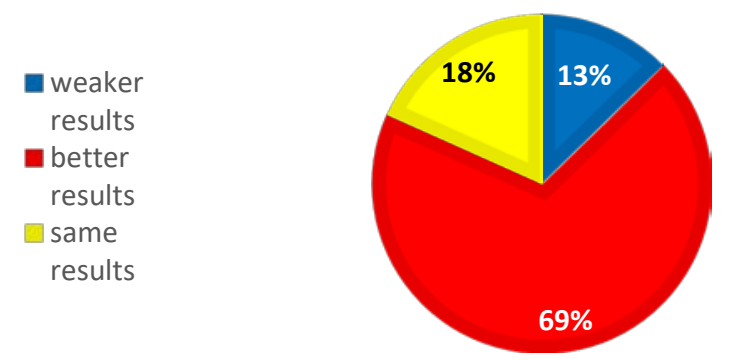

The final results for the lateral lunges revealed that 49 students had progressed, 13 students had the same results and 9 of them had weaker results after a semester of physical education. 
Figure 7. Percentage of incline push ups results

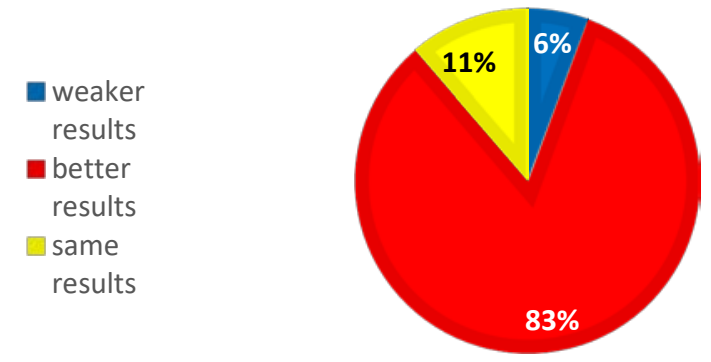

The final results for the push ups revealed that 59 students had a progress, 8 students had the same results and 4 of them had weaker results after a semester of physical education.

After the statistic and graphic interpretation, we could affirm that the students' strength was improved.

\section{Endurance}

Table 3. Endurance results

\begin{tabular}{|l|l|l|}
\hline Statistics & Initial & Final \\
\hline Min & $0-3$ students & $0-1$ students \\
\hline Max & $20-2$ students & $20-6$ students \\
\hline Mean & 8.65 & 11.54 \\
\hline STDEV & 4.28 & 4.42 \\
\hline
\end{tabular}

Figure 8. Endurance means

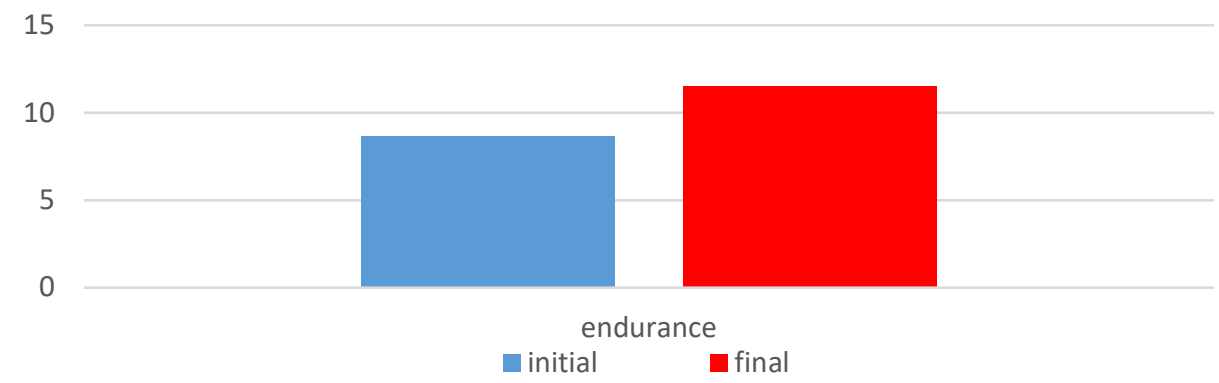

At the end of the first semester, we noticed an improvement of endurance means - 11.54 compared to 8.65 at the first assessment. At the initial assessment, we recorded that 3 students couldn't perform even a burpee and 2 students performed 
the maximum number of burpees. At the final assessment, only 1 student couldn't perform even a burpee and 6 students performed the maximum number of burpees.

Figure 9. Percentage of endurance results
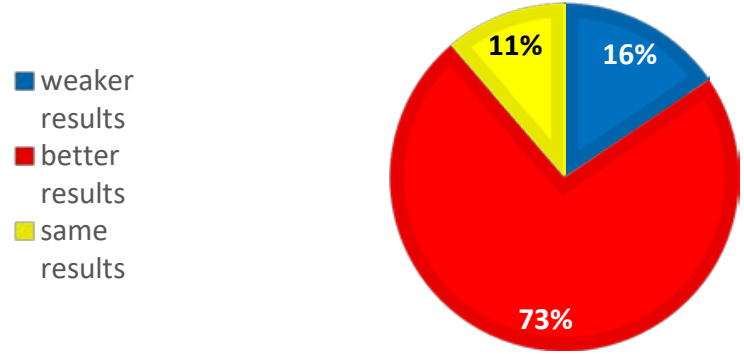

The final results for endurance revealed that 62 students had progressed, 8 students had the same results and 11 of them had weaker results after a semester of physical education.

After the statistic and graphic interpretation, we could affirm that the students' endurance was improved.

\section{Coordination}

Table 3. Coordination results

\begin{tabular}{|l|l|l|}
\hline Statistics & Initial & Final \\
\hline Min & $0-11$ students & $0-3$ students \\
\hline Max & $10-31$ students & $10-50$ students \\
\hline Mean & 6.11 & 7.92 \\
\hline STDEV & 4.19 & 3.52 \\
\hline
\end{tabular}

Figure 10. Coordination means

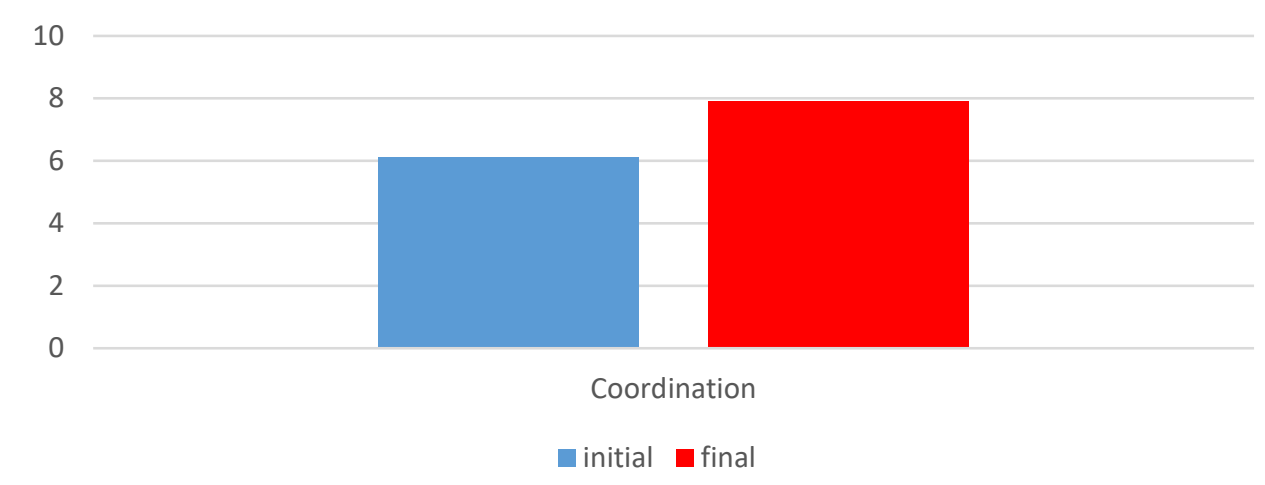

At the end of the first semester, we noticed an improvement of coordination means - 7.92 compared to 6.11 at the first assessment. At the initial assessment, we 
noted that 11 students couldn't do any jumping-jacks and 31 students did the maximum number of jumping-jacks. At the final assessment, only 3 students couldn't perform any jumping-jacks and 50 students performed the maximum number of jumping-jacks.

Figure 11. Percentage of coordination results
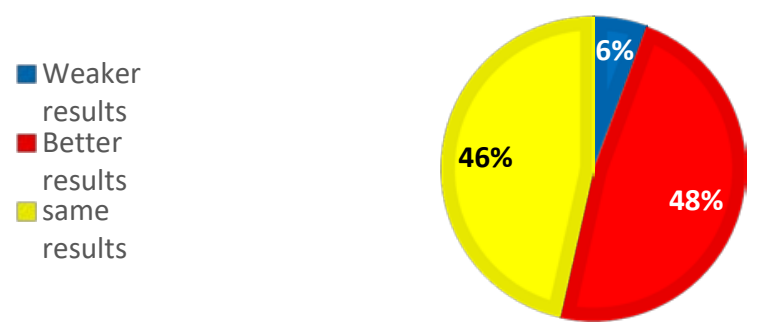

The final results for coordination revealed that 34 students had progressed, 33 students had the same results and 4 of them had weaker results after a semester of physical education.

After the statistic and graphic interpretation, we can say that students' coordination has been improved.

\section{Physical exercises}

Table 4. Physical exercises results

\begin{tabular}{|l|l|l|}
\hline Statistics & Initial & Final \\
\hline Min & $1-62$ students & $1-58$ students \\
\hline Max & $7-2$ students & $7-2$ students \\
\hline Mean & 1.39 & 1.49 \\
\hline STDEV & 1.22 & 1.33 \\
\hline
\end{tabular}

Figure 12. Physical exercises means

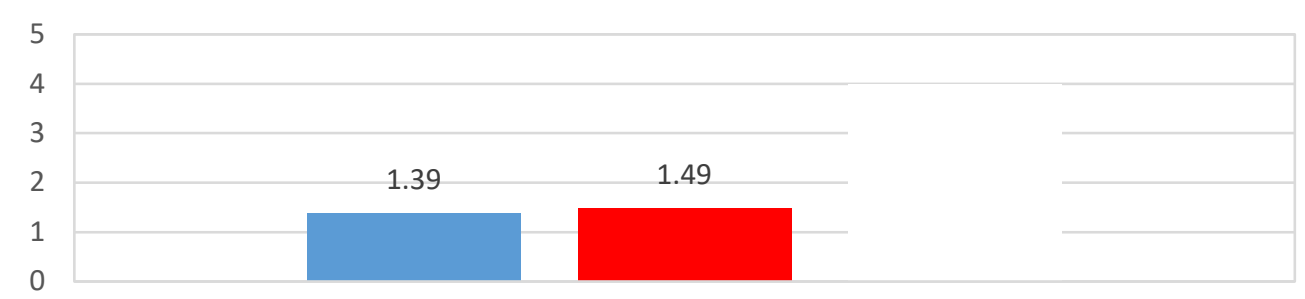

Physical exercises

anitial a final 
At the end of the first semester, we didn't notice a significant improvement of physical exercises practice mean - 1.49 compared to 1.39 at the first assessment. This is an unsatisfactory result because the recommendation of the World Health Organization is to exercise 3-4 times per week.

At the initial assessment we noted that 62 students did physical exercises only during physical education classes and only 2 students did physical exercises every day. At the final assessment, 58 students did physical exercises only during physical education classes and the same 2 students did physical exercises every day.

Figure 13. Percentage of physical exercises results

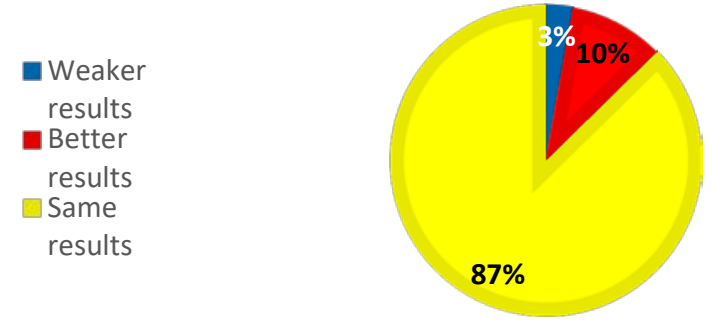

The final results for practicing physical exercises revealed that only 7 students have started practicing more than once a week, 60 students had the same results and 2 of them have given up exercising more than once a week.

After the statistic and graphic interpretation, we couldn't say that the students' physical exercising has been improved. It is worrying that students practice exercises only during compulsory physical education classes.

\section{Conclusions}

- Physical education classes and sports have a positive impact on students' physical abilities.

- After a semester of physical education classes, the physical condition was improved.

- A good level of flexibility is important for preventing joint and muscle injuries and it improves range of motion and joint function.

- An optimal level of strength increases muscle tone, which helps maintain a correct body posture.

- A high endurance capacity provides a strong basis and stability for overall health and it helps to cope with sustained efforts in everyday life.

- Good coordination is important in order to perform smooth and efficient movements.

- If the physical education classes were not compulsory more than 80 percent of students would not do regular physical exercises. 
- The lack of the young generation's interest in exercise is a major problem both for physical and mental health.

- For a future employee, it is important to have an optimal development level of physical abilities in order to perform work tasks.

\section{REFERENCES}

1. Ceban I., 2016, Unele Particularități De Educare A Calităților Motrice La Studenții Din Grupele De Perfecționare Sportivă, in Conferinţa ŞtiinţificoPractică Internaţională Educaţia Incluzivă: Dimensiuni, Provocări, Soluţii., IInd Edition 07.10.2016, pp. 73-76

2. Dominteanu T., 1999, Argumente pentru o metodă de creştere a forţei maxime, prin exerciţii de control a mişcării - A VIII-a Conferinţă Naţională de Stiinţa Sportului: „Managementul viitorului în activităţile de educaţie fizică şi sport”, Centrul de Cercetări pentru Probleme de Sport, Bucureşti;

3. Dominteanu T., 1998, Cercetare cu privire la nivelul dezvoltării calităţii motrice-forţa, la elevii din învăţământul gimnazial- Sesiunea de Comunicări Stiinţifice: „Tendinţe actuale în educaţia fizică şi sport”, Universitatea Ecologică Bucureşti, Bucureşti;

4. Dragnea A., Bota A., 1999 Teoria activităţilor motrice, Publisher: Editura Didactică şi Pedagogicăa, Bucharest http://dspace.usarb.md:8080/jspui/bitstream/123456789/2897/1/Ceban_I_calit ati_motrice.pdf

5. Pop, C., 2015, Meeting Student's Well Being and Educational Goals in Physical Education Classes, in Marathon, vol. 7(1), pp. 138-143

6. Soares de Araujo, C. G., 2004, Flexitest. An Innovative Flexibility Assessment Method, Publisher: Human Kinetics, United States of America

7. Stănciulescu R., 2016, Development Of Basic Physical Qualities, Essential Condition For Creating A Competitive Physical Capacity, in Buletin Stiințific no. 1 (41), pp. 59-64

http://www.armyacademy.ro/buletin/bul1_2016/Stanciulescu.pdf

8. iedunote.com Ability in Organizational Behavior: Types of Ability (Explained), https://iedunote.com/ability.accessed on 23.06.2019

9. en.wikipedia.org, Burpee, accessed on 23.06.2019 https://en.wikipedia.org Burpee_(exercise) 